\title{
Compassionate Exclusivism: Relational Atonement and Post-Mortem Salvation
}

\author{
Aaron Brian Davis \\ Union Presbyterian Seminary
}

\begin{abstract}
Faithful persons tend to relate to their religious beliefs as truth claims, particularly inasmuch as their beliefs have soteriological implications for those of different religions. For Christians the particular claims which matter most in this regard are those made by Jesus of Nazareth and his claims are primarily relational in nature. I propose a model in which we understand divine grace from Jesus as being mediated through relational knowledge of him on a compassionately exclusivist basis, including post-mortem. Supporting this model, I draw from Eleonore Stump's hypothesis in her 2018 Atonement that the crucifixion of Jesus opens the divine psyche to all human psyches sufficiently for salvific mutual indwelling to occur, and from Gavin D'Costa's conception of the descensus Christi ad inferos as the mechanism for grace's accessibility post-mortem presented in his 2009 Christianity and World Religions. This model seeks to address ongoing, justified pastoral concern for the soteriological status of nonChristians while still treating Christianity as objectively true.
\end{abstract}

\section{Introduction}

In her 2012 article What's the Use of Exclusivism?, Mara Becht finds that the staying power of exclusivist soteriologies is bolstered by their focus "on how religious claims are epistemologically formulated and function regarding the salvific efficacy of religious traditions" (51) because ordinary religious people typically view their beliefs as truth claims. For Christians, the truth claims that matter most are Jesus's in the canonical Gospels. Therein, when Jesus speaks about himself, he appears most concerned with people's relational knowledge of him. For example, when discussing who he is in Matthew 16, Jesus asks Peter in verse 15: "Who do you say that I am?"1 The question is about Peter's understanding of Jesus as a person in relation to himself.

${ }^{1}$ Scriptural references are from the New Revised Standard Version. 
It seems of great importance to Jesus that people know him relationally, that they know him in some intimate sense not reducible simply to propositional statements that. Therefore, I propose a soteriology which should be amenable to those viewing Christian beliefs as truth claims while also addressing concern for the salvation of non-Christians: salvific grace is accessible on a compassionately exclusivist basis to all persons, including post-mortem. ${ }^{2}$ This position is compassionate because it describes grace through Jesus as available to all persons in all times and places. It is also exclusivist because of the inherent exclusivity of relationality with God postmortem. Knowing God as God is necessarily implies the counterfactual knowledge of not knowing God as God is not. Inasmuch as this sort of exclusivity is required for the beatific vision's intimacy, this is the sense in which salvific grace mediated through Jesus can be said to be exclusivist.

\section{Stump's Marian Interpretation}

In her recent construction of a "Marian interpretation" $(2018,378)$ of the atonement, Eleonore Stump begins with a Thomistic ${ }^{3}$ view of satisfaction writing that "for Aquinas, unlike Anselm, a wrongdoer's satisfaction does not enable God's forgiveness; rather God's forgiveness and love operating in the wrongdoer enable the wrongdoer's satisfaction" (63). This can be difficult to grasp because "we typically think of a person's being satisfied if he has gotten enough. But the sense of satisfaction for Aquinas is a matter of giving enough" (102). Satisfaction is medicinal for us rather than necessary for God. Divine-human communion is understood by Stump in the terms of Thomistic love, which requires both a desire for the good of the beloved and a desire for union with the beloved (40). Additionally, union of the kind wanted in the second desire requires mutual closeness and significant personal presence (128133) between involved parties.

Closeness comes in degrees and is inclusive of more than just physical proximity, meaning it is possible for one person to be close to another without there being mutual closeness between them. That is, "two persons could be close to each other and still not united to each other because something separates them even while they remain close during that separation" (128). Elsewhere Stump elaborates that closeness is irreflexive, asymmetric, intransitive, and requires self-revelation on the part of involved persons in order for mutuality to be achieved $(2010,120)$. Likewise, "personal presence comes in differing degrees and kinds. There is the minimal kind which can arise when one momentarily catches the eye of a stranger on a bus. At the

\footnotetext{
2 My thanks to the participants in Union Presbyterian Seminary's fall 2019 theology colloquium (especially its organizer, Dawn DeVries) and to those at the 2019 AAR Christian Systematic Theology Unit session at which earlier versions of this paper were presented. I am also grateful to this paper's anonymous reviewers and its editors whose thoughtful criticism and comments have been greatly fruitful, as well as to Fergus Scattergood who provided sharp contributions throughout. ${ }^{3}$ Abbreviations for Aquinas's texts: ST - Summa Theologiæ; SCG - Summa Contra Gentiles; QDV Questiones Disputatae de Veritate; CT - Compendium of Theology.
} 
other end of the scale, there is the kind of intense and intimate mutual personal presence that is possible between two persons who are close to each other and engaged in mutual gaze" $(2018,129)$. Being omnibenevolent, omniscient, and omnipresent, God already fulfills all the requirements for loving communion with human persons that God can, but this love requires reciprocality. If human persons do not will the desires of love for God, God cannot force them so to do without violating love principally. Additionally, human persons face internal, psychic barriers which can restrict their willing of the desires of love for God: guilt and shame. In our guilt, primarily an issue for the first desire, we anticipate anger or retribution (real or imagined) from the perceived offended party; in our shame, primarily an issue for the second desire, we anticipate rejection or abandonment (real or imagined) from those around us (45). Both guilt and shame are capable of distancing us from God and we, in our guilt and shame, need a defeater for them.

Stump proposes that Christ's atonement be understood as God's means for providing a way for human psyches to intimately, metaphysically indwell the divine psyche such that guilt and shame are defeated and the fullness of communion with God is enabled. This work is primarily accomplished through Christ's crucifixion, and chiefly visible in the cry of dereliction. Christ, being divine and human, can likely mind-read human persons in ways not possible for the rest of us (134-135). "Mindreading" is the means by which "one person somehow has within herself something of the mind of another" (130). ${ }^{4}$ There are fascinatingly complex neuropsychological systems (e.g., mirror neurons) which enable mind-reading 5 and "in mind-reading, there is a sense in which one person has a kind of intuitive entrance to the thought, affect, and intention in the mind of another person" (131). One might, for example, know someone is sad and feel something of that sadness just by looking at them because of mind-reading.

In Christ's case, "since immaterial eternal God is present to every time and space, Christ can use his human mind and the power of his divine nature to mind-read at once the entire mind of every human being existing at every time and space" (164). According to Stump, as Christ is crucified and bears the sins of humanity what occurs is a divine mind-reading of all human persons in which the divine psyche is opened to all human psyches, our guilt and shame washing horrifyingly over him:

Flooded with such a horror, Christ might well lose entirely his ability to find the mind of God the Father ... Furthermore, because in his psychic connection with the evil in every human being, Christ would also have the simulacrum of the stains on the soul accompanying all that evil, and he would feel the moral ugliness of that evil in himself. In that condition, why would he not feel abandoned by God? ... In addition, there is undoubtably shame for Christ in his mode of death... A noble soul might find a way to rise above such shame. In such cases, a great-souled person might still see himself as lovely by a higher standard, which measures moral and spiritual worth, as distinct from ordinary

\footnotetext{
${ }^{4}$ See also Stump (2010, 65-70).

${ }^{5}$ See also Stump (2010, Ch. 4), Bohl (2015), Muthukumarsawamy and Singh (2008).
} 
worldly goods. But this move is not readily available to Christ when he is mired in the painful simulacrum of the stains of accompanying all human moral evil. The shame of his mode of death must be dwarfed by the feeling of that inward experience of human moral vileness. (165)

This simulacrum of humanity's evil causes Christ's cry, and "this openness on Christ's part to all human psyches is ... Christ's contribution to mutual indwelling between God and human persons" (166). In taking our guilt and shame upon himself Christ "establishes at one and the same time an indwelling in God of all human beings even in their sinfulness" (166). The guilt and shame distancing us from union with God have been borne by God, turning the tables such that human wretchedness, real or imagined, cannot stand between us and God. A Divine-human union is created through Christ's work which "is ontologically greater than any union possible between two human persons" (166) and "because God is one of the relata, what is shared in the mutual indwelling of God and a human person in grace are the persons themselves, not just their characteristics. What is within each of them, one might say, is both of them" (166). Therefore, even in our guilt and shame we can mutually indwell God thereby turning guilt and shame into honor, for "it is hard to see what could count as a greater honor than being deified" (357). What remains for us then is to cohere around the desires of love for God.

As an anti-Pelagian, Stump does not suggest we will these desires without God's grace; to will the desires of love for God we must first quiesce. In quiescing we cease to struggle against God, allowing the Holy Spirit to infuse in us grace and cooperate ${ }^{6}$ with us to will the desires of love for God (206-210). Stump writes of a person, "Paula,"7 in such a state: "When God gives Paula the grace of justifying faith while her will is quiescent, God is infusing grace into Paula's will when it has ceased to reject grace but has not yet accepted it either... Paula's will is just inactive. But the inactivity is a surrender, not a mere calm of indifference, because in moving into that quiescence Paula feels her quiescence as a letting go of resistance to God and God's grace" (208-209). This is a kind of justification by faith for Paula, "in the sense that the whole process of sanctification will reach its ultimate conclusion in heaven provided only that she has faith and continues in faith" (204). I broadly accept Stump's Marian interpretation, but we diverge on two points: (1) Stump rejects

\footnotetext{
${ }^{6}$ Simon Kittle has criticized Stump's view of quiescence as presenting human persons as too passive to actually be in control of quiescing. It seems to me that Stump's distinction between the surrender of quiescence and mere passivity goes a good way towards rebuffing Kittle's critique. However, I will further state that Kittle seems to regard quiescence as something which would need to be within the forefront of conscious in order to be counted as being under the control of an agent. This, to me, undersells the importance of the subconscious as an active, yet often unnoticed, contributor to human agency which is (except in cases of disease, damage, or malformation) still connected to and influenced by the conscious mind, and vice versa. For Kittle's full critique, see Kittle (2015).

${ }^{7}$ Another example of quiescence is in The Great Divorce. An Angel asks a Ghost with a Lizard on his shoulder (which represents lust) if he might kill it. The Angel says the Lizard cannot be killed without the Ghost's consent, but the Ghost cannot quite manage that. All the Ghost can muster is to say "Damn and blast you! Go on, can't you? Get it over. Do what you like" (Lewis 2002, 524).
} 
soteriological exclusivism, and (2) Stump does not believe that post-mortem salvation is possible.

\section{Dreams and Personal Knowledge}

In (2) Stump maintains "the state of a person at the end of the little portion of his life in this world determines his state in the infinitely extended portion after death" $(2018,42)$. The reason for this outlook is found in Aquinas's understanding of the relationship between the intellect and will. Aquinas understands the will to be an appetite for the good (ST I. Q82. A. 1-2) ${ }^{8}$ wherein goodness "means goodness in general, not this or that specific good thing; that is, the will is an inclination for what is good, where the phrase 'what is good' is used attributively and not referentially" (Stump 2003, 278). At bottom, God is "what is good," meaning that all good "is called good by reason of the similitude of the divine goodness belonging to it" (ST I. Q6. A4. Co.), and the ultimate good for human persons is communion with God (ST I-II. Q3. A8). In beings possessing an intellect and a will ${ }^{9}$ the two are related hierarchically, the former making determinations and presenting them for the latter's use. Stump charts Aquinas's view of the intellect and will as follows, denoting each by I and W:

I1: The intellect's determination that a particular end, under a certain description, is good now in these circumstances.

W1: A simple volition for that end.

I2: The intellect's determination that that end can be achieved by the willer, that the achievement of the end through some means is now and in these circumstances in the power of the willer.

W2: Intention: an act of will to try to achieve the end through some means.

I3: Counsel: the intellect's determination of the means suitable to achieve the end wanted. \{If there is only one such means, then W3 collapses into W4, and I4 is omitted.\}

W3: Consent: an act of will accepting the means the intellect proposes.

\footnotetext{
${ }^{8}$ See also SCG II. A47.

${ }^{9}$ Aquinas believes it possible for a being to, in a sense, have a will (or "natural appetite") without having an intellect (though the opposite is not true). Though not entirely analogous to something like a human person's will it is useful here for comparative purposes. For example, consider a Venus flytrap (Dionaea muscipula) that has the small trigger hairs on its inner surface stimulated by an insect. The flytrap does not cognize that it is good for it to consume insects, but the flytrap does, in a way, will to do just that when an insect enters its vegetative maw. This is the sense in which Aquinas believes beings without an intellect can possess a will; it is in the natural sort of sense in which all living creatures pursue goods for themselves such as eating, reproducing, etc. despite not cognizing the goods as good (SCG II. A47; ST I. Q59. A1. Co). See also Stump (2003, 278-279).
} 
I4: The intellect's determination that this means is the best at this time in these circumstances.

W4: Electio: an act of will selecting the means the intellect proposes as best.

I5: Command: the intellect's imperative, "Do this!"

W5: Use: an act of will to exercise control over one of the things subject to the will, for example, a part of the body, the intellect, or the will itself. $(2003,289-$ 290)

Central here is a person's knowledge. It is only with knowledge pertaining to any given circumstance that the intellect can make the determinations necessary for I1I5 to culminate ${ }^{10}$ in a use of the will. ${ }^{11}$ This means that if one is to change their use of will they must have either sufficient new knowledge or sufficient reordering of old knowledge such that their intellect's determinations might change.

However, Aquinas believes that neither the saints in heaven nor the sinners in hell (SCG IV. A92-93) can change their wills post-mortem. It is those in hell with which I am concerned here, and Aquinas believes that those who, through the faulty determinations of their intellect and wrong-purposed use of their will, died willing mortal $\sin ^{12}$ still so will post-mortem (SCG III. A143). The issue for the damned seems to be that their intellects can apprehend no new knowledge which can alter their determinations and, therefore, their uses of will which have divorced them from God. This point I will concede for present purposes, but is it also impossible for a damned individual to reorder their ante-mortem knowledge sufficiently to change their use of will? Aquinas seems to think not ${ }^{13}$ but I disagree due, in part, to contemporary dream research.

In Big Dreams Kelly Bulkeley challenges the not uncommon notion that dreams are "nothing but chaotic noise, the arbitrary byproducts of automatic physical processes that occur in the brain while we slumber" $(2016,95)$. This challenge has two fronts which are relevant here: physiological/neuropsychological data collected from dreaming subjects, and the continuities/discontinuities of dreams with the waking lives of subjects. Regarding the former, Bulkeley observes that the idea that dreams are simply junk products of brainstem activity during rapid eye movement (REM) sleep is contravened both by studies showing non-REM sleep includes a great

\footnotetext{
${ }^{10}$ However, "in general, where the action is simple and the character of the agent is harmonious and well integrated, I1-W5 are likely to occur seamlessly and tacitly. Their distinctiveness is easier to see in cases where the action is complicated or difficult and/or when the agent has serious internal conflicts" (Stump 2003, 291).

${ }^{11}$ For example, consider a hungry person presented with a bowl of soup, fork, and spoon. In order for their intellect to determine at I4 that the spoon would be a better means for eating the soup than the fork the person must first know that the spoon is better suited for transporting small amounts of liquid from a vessel to the mouth than the fork.

12 Willful sin that is grave in nature (Catechism of the Catholic Church 1997, 454-456).

13 Though this conclusion is not initially clear on my reading of Aquinas, this is how Stump understands his philosophical psychology to be at play here and I am inclined to agree: Eleonore Stump, email to the author, May 3, 2019.
} 
deal of dreaming (97) and by neuropsychological findings indicating a number of areas outside the brainstem are involved in dreaming (98-99). Furthermore, Bulkeley's analysis of numerous sets of dream reports ${ }^{14}$ reveals undeniable patterns in the dreams of slumbering subjects which should not exist if dreams are totally disconnected from waking life and random. In sum, "the evidence from the scientific study of dream content does not support the claim that dreaming is nothing but neural nonsense" (111). Regarding the latter front, Bulkeley finds significant continuities between subjects' waking and dreamed experiences in areas such as: sexuality, social relationships, daily activities/routines, long-term interests/conceptions/concerns, religious outlook, personality/temperament, and cultural ideals/conflicts (122).

These empirically identifiable continuities between subject dreams and waking lives are undeniable, ${ }^{15}$ but equally undeniable are the discontinuities between dreaming and waking. Bulkeley acknowledges that "we cannot prove that all aspects of dreaming are meaningful, any more than we can prove all dreams are nonsense" (129). However, perhaps "the discontinuities between dreaming and waking life can also reflect meaningful dimensions of an individual's life" (129). Bulkeley invites us to consider that some discontinuities within dreams might be indicative of the mind's ability to utilize metaphorical thinking and reasoning. "Seen in this light, dreaming can be defined as imaginative play in sleep" (129). Bulkeley partly bases this view of dreams on his blind analysis of a set of 100 dreams reports in which he observed, in allowing for literal continuity between dreaming and waking and metaphorical continuity, some aspects of subjects lives were readily discernable. ${ }^{16}$ Therefore, in at least some cases, discontinuities in dreams might also reflect something of subject waking lives, albeit in more imaginatively playful scenarios. ${ }^{17}$ After all, myriad species use playful activities as a kind of "safe arena in which to experiment with a wide variety of possible actions and responses to different situations" (137). Seen in this light, aspects of dreams which might appear disparate from waking lives could, in at least some cases, be playful activities of sleeping minds and could include literal and metaphorical currents.

I suggest, if one accepts dreams are not simply neural nonsense, maintain empirically verifiable continuities with our waking lives in areas which are important to the average person, and have discontinuities with waking life which could, in at least some cases, be examples of the metaphorically playful activity of the mind, dreams can help us understand how one might be able to change their will on Aquinas's account, in hell, without any new knowledge. Given that Aquinas does not believe it possible for one to totally cohere around evil (CT. A115), there must be at

\footnotetext{
${ }^{14}$ Recollections of subjects' dreams recorded shortly after waking.

${ }^{15} \mathrm{Helpful}$ also are observed connections between experiences of frustration and satisfaction in waking life and experiences of negative and positive dream themes/subject interpretations (Weinstein, Campbell, and Vansteenkiste 2018, 50-63).

${ }^{16}$ In this case, that the subjects producing the dream reports were end-of-life patients (156).

${ }^{17}$ Also helpful are indications dreams bear functional similarities to waking mind wandering (Occhionero and Cicogna 2016, 962).
} 
least some good in every damned person, however morally deformed. Further, he supposes the dead remain personally continuous with their living selves (e.g., they remember who they are and their lived experiences) (SCG IV. A81, A84) and retain the intellective senses of their minds (ST Suppl. Q70. A1. Ad.2). ${ }^{18}$ In such a state and with such faculties as the above, I see no reason why a damned person's mind might not be capable of something like the dreams of which they were capable ante-mortem. This is not to suggest they sleep and wake as they did ante-mortem. Rather, I suggest, if the mind is capable of the kind of powerful, intimately personal, and entirely internal processing and play seen in dreaming, it seems we ought not to simply deny such a faculty, even if it is not entirely analogous to dreaming, to the minds of the damned on Aquinas's account. ${ }^{19}$ Such a faculty could allow an individual's knowledge to be reordered and represented freshly such that a damned person could change their use of will, quiescing such that they might be saved. ${ }^{20}$

For example, consider an individual living in the midst of a bloody conflict between militarized religious forces. If they see this horrible state of affairs as chiefly attributable to religion and belief in deity then their intellect might at I1 determine that the rejection of both is a good (for if all were to do this then there might, in this person's thinking, be no more conflicts of the kind through which they suffer), ultimately resulting in a use of will at W5 whereby both are totally eschewed. However, imagine this person's dreaming mind presents to them a kindly priest they knew in childhood being murdered by opposing forces as he helps shield a group of children from gunfire. This dream might lead our hypothetical individual to consider the religious motivation of the priest's selfless act which might in turn move their determination at I1 to I3, meaning that their intellect would be determining whether rejection of religion and belief in deity is the best way to prevent conflicts like the one through which they are suffering rather than simply assuming it. In this circumstance it would be possible for this individual to consent at W3 to exploring the care for others represented in the priest's sacrifice, resulting in a use of will at W5 to remain open to the potential goods of religion and belief in deity. Given enough time, it is further possible that this person might determine practicing religious faith like the priest's would be the best way to prevent conflicts like the one through which they suffer; perhaps they might even come to a place in which they quiesce to the Spirit's

\footnotetext{
18See also $Q D V Q 19$. A.

19 Though it is noteworthy that such reorientation might not necessarily require an intermediate state per se. Perhaps, if Christian physicalism proves true, such could occur nearly instantaneously at the moment of the general resurrection or of death. Anyone who has done much dreaming is familiar with the phenomenon in which staggering lengths of time can seem to pass within our minds while our clocks have only jumped forward slightly. Alternatively, perhaps the parousia occurring at a time T might include a hypertime of the sort Jonathan Rutledge (2018) suggests within which those requiring said might be placed by God at $\mathrm{T}-1$ and wherein they find themselves alive again and able to change their intellect's determinations. Both seem possible, but neither are views I intend to take up or defend here. My thanks to Rachel Baard for bringing this possibility to my attention.

${ }^{20}$ It may be beneficial to explicitly state that there is here an assumption that the intermediary state is temporal. I am not prepared to go to print with a particular articulation of what such might look like, but for an interesting discussion of some possibilities see Walls $(2010,114-122)$.
} 
infusing of justifying grace into them! If such a movement can be imagined for a living person, it seems possible to imagine similar situations for the damned if the core faculties necessary for such a thing remain intact.

I turn now to divergence (1): soteriological exclusivism. To Stump, faith is "the necessary and sufficient condition for salvation from sin and for the attainment of shared union with God" $(2018,204)$. Quiescence is the beginning of salvific faith and is our justification. Sanctification, persevering in faith, is also required as the two together unite us "in ever-increasing degree, with God in love" (206). Typically, some sort of profession of faith in Christ has also been assumed to be requisite for saving faith. The specifics of what such might entail vary widely, but Christ's claim in John 14:6 that no one comes to the Father except through him is often used representatively. Stump remarks that this passage "is the expression of a kind of exclusivism. In fact, any worldview excludes others" (282). That being said, she remains troubled by the "apparent implications" (283) of Christian exclusivism because she believes it is incompatible with God's love. Stump asks how a loving God could exclude from salvation those who have never heard of Christianity, who die before the age of reason, or those born before Christ's incarnation (283)?

Her solution is to propose that "one can have a loving connection to the person who is Christ, even while one rejects the theology about Christ" (283). Stump clarifies by referring back to her interpretation of the cry of dereliction as opening the divine psyche to all human psyches, including those without Christian theological beliefs or who never surrender to the indwelling of the Holy Spirit as such. In fact, she cites the biblical account of David's anointing by the spirit of the Lord as warrant for the notion that one can be indwelled by the Holy Spirit without need of Christian theological beliefs (286). And so "the one thing needful for salvation, then, is not an acceptance of Christian theological doctrines or a commitment to a set of Christian beliefs, but rather coming to Christ" (289). I so nearly agree; in this life affirming certain theological propositions guarantees neither salvation nor damnation. However, I believe saving faith must include foundational propositional knowledge (FPK) of God in order for the full intimacy of the beatific vision to be enjoyed.

FPK of God is that knowledge which if lacked or rejected fundamentally changes one's understanding of God; its "inclusion" in one's faith does not mean that they must cognize it as such. For example, if one, upon encountering God postmortem, can accept that God is indeed one it matters not whether they have ever heard or explicitly affirmed the Shema. Essentially, what is required is that one at least have a disposition to accept God as God is upon encountering God post-mortem, the reason being that the retention of false beliefs regarding who God is will otherwise impede interpersonal intimacy between the deceased and God. ${ }^{21}$ Determining what constitutes FPK is difficult, but it seems that we are best served here by the creeds of the ecumenical councils. ${ }^{22}$ Like Marilyn Adams, I consider the creeds "to be normative

${ }^{21}$ I am grateful to Andrew Moon for his comments here.

22 Which councils are considered ecumenically authoritative will vary based on one's tradition. There is no space here to articulate any satisfactory argument for the authority of particular councils and so 
in the sense of being systematically entrenched" $(2006,105)$, and it here becomes important to distinguish between creedal doctrines (the essential teachings of the creeds) and creedal models (the straightforward understanding of the creeds as paradigmatic). ${ }^{23}$ We can think of creedal doctrine as the theological core of a given creed and creedal models as explications of said core. That is to say, FPK does not consist in simply each proposition within each conciliar creed but in the theological premises undergirding them. ${ }^{24}$

For example, one facet of creedal doctrine from Chalcedon is that God truly became human while remaining truly divine, ${ }^{25}$ whereas Christ's being "from two natures" or "in two natures" concerns creedal models. Creedal doctrine is the revelation of who God is; ${ }^{26}$ creedal models are our attempts to plumb the depths of that revelation in our finitude. ${ }^{27}$ The former has to do with the indispensable truth of Christ in relation to us, the latter has to do with the technical understanding of said which can so often be hindered by the limits of the human tongue and mind. Creedal doctrine is, therefore, the sort of thing I mean to describe regarding FPK of God, particularly that revealed by Christ. Consider the difference it makes in conceiving of God as one who would never take on weak, finite, squishy, human existence. Another example of creedal doctrine is found in the Nicene-Constantinopolitan declaration of God's tri-personality. That God is three persons rather than some other number is creedal doctrine whereas the numerous debates in Trinitarian theology over the economic and immanent Trinity, Latin Trinitarianism and social Trinitarianism, and the procession of the divine persons (or lack thereof) and their ordering all pertain to creedal models. Consider the difference it makes in conceiving of God as one who could not possibly be the Father and the Son and the Holy Spirit. In both cases such a God would be fundamentally different than historic understandings of God in Christianity.

However, it could be argued, as Matthew Benton has, that "interpersonal knowledge is autonomous relative to any particular propositions known about a person in this sense: for any set of propositions one knows about someone, one could know that someone interpersonally without knowing those propositions about them" $(2017,821)$. This argument, if successful, might seem to render something like FPK

I will suffice it simply to state that, as an Anglican, I view the first seven ecumenical councils as such and relevant here.

23 This distinction is from Richard Plantinga, Thomas Thompson, and Matthew Lundberg (2010, 250).

${ }^{24}$ For example, if a person mistakenly believes that Christ was crucified under Coponius, not Pontius Pilate, such will not matter so long as they will the desires of love for the God with pierced hands and side post-mortem.

${ }^{25}$ Furthermore, Chalcedon more so drew boundary markers around orthodox Christology than it thoroughly explored all Christological desiderata (Coakley 2002).

${ }^{26}$ R.A. Wellington seems correct that "the sentences of old creeds, if not fixed by definite propositions, cannot ward off revisionist attempts to reinterpret these sentences in a way that is alien to their original context" $(2019,157)$. The content which "fixes" the creeds would here be creedal doctrine.

${ }^{27}$ My understanding of the breadth/limits of human talk about God is influenced by Stephen Need (1996). 
wholly unnecessary, but this would be to view the matter rather backwards. While interpersonal knowledge might be autonomous of any particular set of propositions about a person it does not follow that interpersonal knowledge is therefore separable from all propositions. In fact, nearly any ${ }^{28}$ case of interpersonal knowing necessitates at least some propositional knowledge being gained. It is simply the case that for any given set of propositions one might know about a person they might have known others instead. But this explanation might seem to render the situation worse for FPK given that it would indicate there is no particular set of propositions necessary to knowing God interpersonally. Recall though two key points: the inclusion of FPK in one's faith merely requires their having a disposition to accept God as God is upon encountering God post-mortem, and the beatific vision is an experience of the utmost intimacy with God. With these points in mind it becomes helpful to consider the de dicto/de re distinction as pertains to knowing God.

In their discussion of what sort of belief might be necessary for personal relationality with God, Ted Poston and Trent Dougherty write that "belief de dicto (of the dictum or proposition) is the endorsement of some proposition that is preceded by a that-clause ... Belief de re (of the res or thing) is belief of a thing or individual that it has some feature even if the de re believer does not recognize the subject under some specific description" $(2007,185)$. When considering whether de dicto belief is required here they fall on the side of the negative but clarify that "it would be a mistake to think that to suggest that de dicto belief is not necessary for a meaningful relationship with God is to suggest that de re belief is sufficient for all God wants for us" (192). If we understand FPK as consisting in knowledge de dicto, then FPK is not necessary for a meaningful relationship with God in this life as persons may come to know God de re through manifold avenues. However, this more minimal de re knowledge cannot persist post-mortem. For, as Benton writes elsewhere, "if we suppose that interpersonal knowledge is the ideal relation through which God unites God's self to humans, then one proposal is to view interpersonal knowledge ... as the resultant cognitive relation which can only be gained by our ascending through perceptual contact to objectual knowledge ... which treats God second-personally as subject ... and that this stage of participation importantly involves gaining propositional knowledge, and perhaps even understanding, of the correct guises or descriptions which apply to God" $(2018,438)$. Here Benton writes with regard to "liturgical knowledge" (437-439) but it seems the same view can be applied to the dead.

The anticipated perception of God by human persons post-mortem is one substantively different to present perceptions of God, particularly regarding its immediacy. As Paul writes: "For now we see in a mirror, dimly, but then we will see face to face. Now I know only in part; then I will know fully, even as I have been fully known" (1 Cor. 13:12). We might say then, with Jerry Walls, that salvation in the

\footnotetext{
28 Excepting such cases as Benton's “conman" $(2017,827)$ in which one person specifically and intentionally deceives another by providing false propositional knowledge to them. Such cases are excepted given that it is generally accepted that the Christian God is not a liar and therefore are not strictly relevant to the matter at hand.
} 
beatific vision is fundamentally "a matter of knowing God as fully as we are capable of knowing him and thereby experiencing the fullness of life" $(2002,38)$. Helpful in illustrating the entailments of this perceptive experience is an example from Thomas Senor: "Whereas, for example, one can believe that Santa Claus exists without Santa's actually existing, one cannot perceive that it is raining without it being true that it is raining" $(2017,65)$. While one might be capable of believing that God is as God is not ante-mortem and maintain some relational connection with God such is not the case post-mortem due to the immediacy of our perception of God. One cannot perceive God as God is not because, simply put, there is no such thing to apprehend. In sum, while FPK might not be necessary to ante-mortem human-Divine relationships it is necessary post-mortem due to the perceptual immediacy of such human-Divine interactions and the nature of what is wanted by God for human persons in the beatific vision.

On Stump's account, union of the kind wanted in the second desire of love requires: (A) personal presence and (B) mutual closeness $(2018,119)$. (A) requires "the kind of intense and intimate mutual personal presence that is possible between two persons who are close to each other and engaged in mutual gaze" (129). (B) requires "some parity between the persons in the relationship as regards their willingness to be open to the other, but it does not require symmetry in the depth or degree of what is shared with the other" (123-124). Stump claims conscious awareness of Christ's passion, death, and the theology surrounding said are "the best means for bringing a person to the surrender to the love of God which is requisite for the indwelling of the Holy Spirit. But, even for a perfectly good God, the most promising means are not necessary means" (380). My trouble is that I do not see how a faith non-inclusive of FPK of God can nonetheless be a saving faith post-mortem which brings a person into participation in the profound intimacy of the beatific vision and the new creation.

How are we to understand a person who does not know God as God is nevertheless participating in intimate communion with God? Recall the rejector of Chalcedonian doctrine who believes God too lofty to ever become human. If this person meets the risen Jesus and cannot accept that the God-man is indeed God and man then I fail to see how they could nevertheless participate in the intimacy of the beatific vision (unless we are to assume that God overwrites or otherwise changes their knowledge, which would seem antithetical to the love wanted here). Walls comments that "to find this objectionable, one must think either that there really is no God in the objective sense, or that Christians have no right to take as true their distinctive beliefs about God, or that logically incompatible claims about him can all be true" $(2008,404)$. Of course, Stump's primary objection to something like FPK being requisite for ultimately saving faith is that it seems incompatible with God's love given that such a requirement would seemingly damn all who do not affirm it in this life. Recall though that on a compassionate exclusivist account the opportunity to include FPK in one's faith does not end at death; therefore, this concern is a nonissue. However, an as yet undiscussed facet of this account is how the opportunity for postmortem salvation might occur. 


\section{D'Costa on the Descensus}

The descensus Christi ad inferos is conceptually rooted in the Apostles' Creed and 1 Pet. 4:6, though its nature has been debated since the early Church. ${ }^{29}$ Particularly potent among contemporary accounts of the descensus is Gavin D'Costa's which builds a soteriology conscious of global religious diversity. D'Costa's account delineates three principles he holds together which are also important to compassionate exclusivism for ensuring a thoroughly Christian account of postmortem salvation: "(1) the necessity of Christ, the trinity, and the church for salvation; (2) that holding this first point does not result in a denial of non-Christian religions... nor does it result in a pessimistic attitude regarding the salvation of non-Christians . .. and (3) that the salvation of non-Christians is resolved post-mortem" $(2009,161)$. D'Costa employs a speculative Catholic understanding of the descensus wherein Christ descended to various strata of limbo (conceptual antechambers to hell), ${ }^{30}$ not hell proper.

For example, the souls of Jewish matriarchs/patriarchs who died before Christ's incarnation, and pre-incarnation virtuous pagans (e.g., Plato), are thought to have been in the now empty limbo of the just, but "the key to understanding the emptiness of the limbo of the just is that, from the time of the earliest Christians ... most Christians assumed that, after Christ's resurrection, all peoples choose between the acceptance or rejection of the gospel-there are no longer any other options" (178). We now know this not to be the case; it seems there are many persons who neither explicitly accept nor reject Christ! However, D'Costa's usage of the limbo of the just here does not propose that such persons convert post-mortem, rather they experience "a coming to maturation and completion ... when confronted by Christ in his descent into the limbo of the just. It does not require unconscious desire, but a response to the good news preached by Christ and his church, thereby explaining the epistemological, Christological, and ecclesiological elements that were problematic until this solution is employed" (179). Additionally, D'Costa is careful to note that "hell, like heaven, does not properly speaking have any time and space location but both affirm ontological realities" (165). We, therefore, should not think of Christ's descent as like his visiting Jerusalem in that he was at one time inside and another outside it. Though the descensus may have occurred at some time in the past relative to us, God's simultaneity with all times means God is not limited to applying its effects only to those at one particular time or another; the descensus can include persons who die at any point before or after Christ's incarnation.

This is a powerful suggestion holding together the three principles above well. However, D'Costa mobilizes the descensus within Catholic systematics which need not be adopted unless one happens to share his particular eschatological predilections.

\footnotetext{
${ }^{29}$ As seen in MacCulloch (1930), Trumbower (2001, 91-105).

30 "Limbo" remains an undefined term in Catholicism despite its usage by various Catholic theologians working in soteriology/eschatology and in the International Theological Commission's prominent document The Hope of Salvation for Infants who Die without being Baptised. For a detailed account, see Dyer (1963).
} 
Having no need for his conceptual antechambers, here the eschatological landscape is collapsed into a simpler heaven/hell understanding and it is suggested that Christ descended into hell proper. Further, D'Costa's focus is on those who lived justly antemortem. Since he believes we are "not allowed to make any more free decisions after death" (163-164) his model needs those saved post-mortem to have had righteous inclinations in life which can "mature." But here it is suggested that the damned can alter their wills and so their ante-mortem justness is not strictly necessary for postmortem salvation. It seems to me that living a just life ante-mortem might aid in cultivating a disposition to affirm FPK of God post-mortem given God's omnibenevolence, ${ }^{31}$ but outside this point ante-mortem justness is a non-issue for compassionate exclusivism. The role played here by the descensus is to provide the means whereby dispositional predicates necessary to salvation might be actualized and so is, in some respects, still similar to D'Costa's usage but is also distinct in that it does not strictly require that the dispositions be present ante-mortem.

In other words, the descensus as deployed here ensures that no person is ever cut off from the possibility of encountering and knowing God as God is truly. We might imagine death as like a doorway through which all persons must pass and in which God stands. ${ }^{32}$ Nobody passes through without encountering God as God is and thereby determining through their response to God whether on the other side lies hell or heaven. What the descensus does is make clear that this metaphorical door is not closed to the dead after their having passed through. Whether one believed themselves a Christian in life but finds the God in the doorway unrecognizable, thought there was no God and is surprised to find one, or has some other manner of encounter with Divinity at their death which leads to their finding hell past the door, the chance to form a disposition to include FPK of God in one's faith remains available post-mortem. This stance may seem to violate Aquinas's notion of new knowledge being unobtainable post-mortem, thereby rendering the preceding attention to dreams and cognition superfluous, but given that this encounter with God happens at the moment of death and then merely remains ongoingly available it seems to me that such is not necessarily the case. ${ }^{33}$

\section{Compassionate Exclusivism}

Compassionate exclusivism can be described as compassionate due to the perfect love God shows humanity in offering salvation. Through Stump's Marian interpretation we are presented with a God who loves so perfectly as to go to the very

\footnotetext{
${ }^{31}$ Especially given it seems "that faith involves certain conative states as well as know-how and that these elements are crucial to performing acts of faith" (Sliwa 2018, 262).

32 An image attributed to C.S. Lewis by Stump $(2018,504$ n. 51), though she does not specify from where it is drawn, and I have been unable to locate it.

33 Interestingly, Aquinas believes both the just and unjust in their hells saw Christ in the descensus (ST III. Q52. A2) but does not apparently see a contradiction between this vision and their inability to gain new knowledge post-mortem.
} 
limits of Godhood in offering salvific mutual indwelling to us. Christ's incarnation marries human nature to divine nature and personhood which enables a profound opening of the divine psyche to all human psyches at the cry of dereliction. As Christ hangs upon the cross the sins of all human persons flood his mind, creating a simulacrum of all which, for us, causes alienating guilt and shame. Having but one, divine person, Christ takes these experiences into his mind and, in so doing, provides a defeater for all that separates us from the fullness of communion with God. We all now indwell God, even in our guilt and shame, and all we must do is quiesce to the indwelling of the Holy Spirit so that we can will the desires of love for God.

After Christ dies the descensus occurs and Christ descends into hell. Recall that within the mind we seem to have an extremely capable and entirely internal mechanism whereby old knowledge might be reordered in new ways. The continuity of human persons post-mortem with their ante-mortem selves in terms of knowledge provides a wealth of possibilities with which the human mind could imaginatively play, even if we do not assume that people sleep and dream as such post-mortem. The descensus extends Christ's opening of the divine mind to human persons to include those in damnation such that even post-mortem nothing keeps them from God but themselves. Human persons then, even those who rejected God ante-mortem, might alter their wills in death, quiesce, and be infused with grace by the Holy Spirit such that they could will the desires of love for God.

Compassionate exclusivism can be described as exclusivist because of the inherent exclusivity of relationality with God post-mortem. Knowing God as God is necessarily implies the counterfactual knowledge of not knowing God as God is not. Therefore, if we are to love God as God is post-mortem, and in the eschaton, then at least FPK of God must be included in our faith, otherwise we lack something requisite to the enterprise. We can see this concept illustrated in C.S. Lewis's Episcopal Ghost from The Great Divorce. Even when met by a friend come from heaven to help them, this Ghost cannot embrace God as God is due to their deeply entrenched ante-mortem view of God. When asked if he even believes God really exists, the Episcopal Ghost replies:

Exists? What does Existence mean? You will keep on implying some sort of static, ready-made reality which is, so to speak, "there," and to which our minds have simply to conform. These great mysteries cannot be approached in that way. If there were such a thing (there is no need to interrupt, my dear boy) quite frankly, I should not be interested in it. It would be of no religious significance. God, for me, is something purely spiritual. The spirit of sweetness and light and tolerance-and er, service, Dick, service. We mustn't forget that, you know. $(2002,488)$

This Ghost knows God as God is not, clearly lacking, perhaps even consciously rejecting, FPK of God. How is such a person to be in the fullness of communion with God post-mortem if they cannot consent to cohabitation with God as God truly is? Are we to imagine that God forcefully changes this person's knowledge such that they do include FPK of God in their faith, or that this person can remain ignorant of God as 
God is and yet somehow be within the intimacy of the beatific vision? For God to simply force one to know God in such a way or to be within heaven's intimacy while they do not accept God as God is would undermine the desires of love and the mutuality requisite within them. Therefore, one who knows God as God is not cannot be in the fullness of communion with God until such time as they know God as God is instead.

It may appear as though what is wanted of a person in FPK is too callously expansive in that it seems to require an abundance of propositional data for human persons to affirm. However, recall that what is meant by FPK's needing to be included in one's faith post-mortem is that persons need at least a disposition to accept God as God is because the clinging to of false counterfactuals regarding who God is, as in the case of the Episcopal Ghost, will impede interpersonal intimacy between the deceased and God. Consider here also the experience of Jesus's disciples on the road to Emmaus. We read that "while they were talking and discussing, Jesus himself came near and went with them, but their eyes were kept from recognizing him" (Luke $24: 15-16)$. Why might it be that the disciples do not recognize Jesus whom they have known so closely through the course of his ministry? The text continues by describing the recounting of the testimony of Jesus's women disciples who found the empty tomb which the men seem not to have believed (Luke 24:19-25). M. Dennis Hamm writes that "the testimony of the women, which the readers know is well-grounded and true, has not yet earned the assent of the other disciples. They do not yet have the scriptural framework for understanding a messiah who is executed like a common criminal; and then is raised to new life. That will come in a moment" $(2018,1101)$. Though it is possible that part of their lack of recognition has to do with Christ's having a somewhat different body post-resurrection and thereby looking in some ways different than previously (Keener 1993, 257), a major impediment to their recognizing the risen Christ seems to be their inability to understand that this person could possibly be Christ.

The antecedent Judaism of the day had no conception of an individual resurrection of the sort Jesus experienced (c.f., 1 Kgs. 17:21-24) outside of the general resurrection which might occur at the end of days (Novak 2008, 122-124). Notable here also is that the disciples did come to understand that Jesus was their companion on the road shortly enough (Luke. 24:31-32). So, while it may be that they did not at first understand how it was that this man could be Jesus, by the self-revelation of Jesus as they walked, they came to understand such later. This story represents what I mean to describe as requisite in one's including FPK of God in their faith; if we do not have at least a disposition to accept God as God is post-mortem then the full intimacy of the beatific vision cannot be enjoyed in the same way that the disciples did not enjoy the full intimacy of reunion with their Lord on the road that they might have if they had immediately known it was Jesus who walked with them. The function of creedal doctrine in FPK is not to propose a burdensome amount of propositional content is necessary to saving faith post-mortem but rather to highlight those core propositions (e.g., God is three persons, God became truly human while remaining truly divine, and so forth) which secure, as best we can in this life, a vision of the sort of God we will meet after we die. 
There may remain concern for those who appear incapable of the sort of propositional attitudes necessary for FPK (e.g., infants or those with significant cognitive deficits). Such a concern as pertains to infants is particularly palpable here as Stump herself writes that they are capable of at least a kind of interpersonal knowing of and union with their caregivers (2010, 65-66). However, such knowing seems to be de re and, as stated previously, while knowledge of God de re may be sufficient for relationality with God in some sense said may not be sufficient for all that God desires for human persons. Rather than suppose God permits forever that persons might be restrained from the possibility of knowing God in the fullness God desires I suggest that there is no compelling reason to think persons lacking some faculties necessary to knowing God fully ante-mortem would be so restrained postmortem. We might imagine this reality as something like that posited in the Pneumatological eschatological perspective offered by Amos Yong:

Deceased infants - whether healthy, microencephalitic, or otherwise disabled, whether dead from natural or other causes-would have a glorious and powerful resurrection body .. . measured by their nestedness in the communion of saints and by the redemptive caregiving in the eschatological community . . . Hence there is continuity and discontinuity with the resurrection body: On the one hand, infants are recognizably infants in the eschaton, although, on the other hand, their bodies are no longer subject to decay even as we are unable to fully anticipate the mysterious transformation of the resurrection body. But the work of the eschatological Spirit also means that infants do not stay infants eternally, but are unendingly transformed along with other members of the eschatological community in and toward the triune God. (2007, 18-19)

That is to say, if God desires that human persons know God beyond knowledge de re then it is not necessary to imagine that all differences in ability and so forth are eradicated. One can affirm the possibility of knowing God relationally in some sense sans FPK while also maintaining that FPK is requisite for God's ultimate interpersonal ends for human persons in the fullness of their diversity. The exclusivism of the thesis offered here is, therefore, properly exclusivistic. However, this exclusivism is tempered by God's compassion because in the descensus God provides an opportunity for truly all to encounter God as God is and include FPK of God in their faith.

Stump is rightly concerned with the potentially problematic nature of exclusivism in formulating her Marian view. However, the largest of her concerns, the incompatibility of God's love with exclusivism, is addressed through the possibility of post-mortem salvation via the descensus and the suggestion that the damned can alter their wills and include FPK of God in their faith. If Christ makes God's offer of salvific intimacy to all persons as suggested here, then God's love of all human persons is maintained. The only thing standing in one's way would be themselves. D'Costa, similarly, is rightly concerned that an exclusivism conscious of global religious diversity account for (1) the necessity of the Trinity (particularly Christ) and the church in salvation, (2) a rejection of the denigration of non-Christian religions as 
necessary for exclusivism, and (3) that the salvation of non-Christians might occur post-mortem $(2009,179)$. Compassionate exclusivism accounts for (1) in the active roles the Godhead plays through Christ's crucifixion, the Holy Spirit's infusing grace, and the Church's role in securing relevant FPK through creedal doctrine, (2) in the possibility of justness aiding in cultivating a disposition to ascent to Christ's good news post-mortem (without being strictly necessary), and (3) through the adoption of the descensus as the means through which persons encounter God as God is postmortem and have the opportunity to quiesce and include FPK of God in their faith.

However, it might be wondered if the sort of post-mortem cognition supposed here to be possible is at all under the kind of volitional control which would seem to be wanted in a matter of such gravity as one's soteriological status. After all, persons seem to not have much, if any, control over their dreams or what they do in them antemortem so why should we suppose a faculty of this sort would be any more controllable post-mortem? It is not obvious that this concern is as troubling as it may initially seem because it is not decidedly the case that persons have no control of or in ante-mortem dreams. For example, consider the recent findings of Miloslava Kozmová indicating that non-lucid dreamers are, in at least some instances, capable of creative problem solving in their dreams which is indicative of volitional activity $(2017,32-45) .^{34}$ For example, she writes of those engaging in interpersonal problem solving:

In their strategizing efforts, dreamers use both body movement and verbal communication as a way of preventing possible escalation of an already problematic situation. They display cooperative behavior and influence others, they assert their will, they seek advice, they make requests and offer suggestions, or they imitate others' body behavior ... In this case, mental behavior of proposing what could be done otherwise and noticing the lack of one's behavior (albeit generally not valued in the real world) represents an evaluative executive skill. In addition, some dreamers use analytical, interpretative, and reasoning thought. (44)

These apparent instances of decision making are occurring in non-lucid dreaming: dreaming in which the dreamer is not aware that they are dreaming. If nonlucid dreamers, those who would seem to be the most poorly positioned for volitional exertion in their dreams, can be capable at least sometimes of volitional control while dreaming then it seems such a possibility cannot be denied to a deceased person exercising similarly imaginatively playful cognition (especially given that they would not be sleeping and waking as such and therefore the trouble of passing into and out of variable states of consciousness would likely not be present). And since this control is utilized in imaginatively playing with experiences from life and one's encounter of

\footnotetext{
${ }^{34}$ Others go so far as to state that "high-order cognition is much more common in dreams than has been assumed, so any theory of dreaming that does not take this into account is out-of-date" (Kahan and LaBerge 2011, 509).
} 
God as God is then it is perhaps all too possible ${ }^{35}$ that one could eventually reorder their intellect's determinations such that they quiesce, are indwelled by the Spirit, and begin willing love of God as God is post-mortem. ${ }^{36}$

\section{Conclusion}

Compassionate exclusivism is a model seeking to answer soteriological questions in ways that the average person, Christian or not, will be primed to receive. Widespread and myriad representations of the afterlife in popular media evidence a broad interest in soteriology and eschatology. ${ }^{37}$ Furthermore, Brecht shows us that, for Christians, these interests tend to focus on the truth of their own religious beliefs and the soteriological implications for others in light of them. Compassionate exclusivism takes the Christian faith to truly be exclusive in that it is by the work of the Triune God alone that we come into the fullness of communion with our Creator. Christianity is, therefore, regarded as consisting in fundamental truth claims because it is through Christianity that the nature of God's salvific work for humanity has been most fully revealed. However, compassionate exclusivism also takes the love of God to be such that no person is ever separate from God except explicitly by their own desire. My hope, therefore, is that such a view will address both pastoral and epistemological concerns; faith in Christ does not necessitate committal to the idea that all who do not profess such faith in this life are necessarily damned or the denigration of nonChristian religions, neither does it require compromising belief in the objective truth of Christianity.

\section{References}

Adams, Marilyn. 2006. Christ and Horrors: The Coherence of Christology. Cambridge University Press.

Aquinas, Thomas. 2009. Compendium of Theology, translated by Richard J. Regan. New York: Oxford University Press.

.1953. Questiones Disputatae de Veritate: Questions 10-20, translated by James V. McGlynn. Henry Regnery.

\footnotetext{
35 Especially given the role dreams have been observed to play in some ante-mortem conversions (Davis 2005).

36 Perhaps also useful here is the brief engagement of a similar trouble raised by Kittle in note 6 .

${ }^{37}$ As clearly seen in Garrett (2015).
} 
1956. Summa Contra Gentiles: Book Two, translated by James F. Anderson. University of Notre Dame Press. 1956. Summa Contra Gentiles: Book Four, translated by Charles J. O’Neil. University of Notre Dame Press. 1956. Summa Contra Gentiles: Book Three, Part I, translated by Vernon J. Bourke. University of Notre Dame Press. 1956. Summa Contra Gentiles: Book Three, Part II, translated by Vernon J. Bourke. University of Notre Dame Press.

1948. The Summa Theologiæe of St. Thomas Aquinas, translated by Fathers of the English Dominican Province. Ave Maria Press.

Benton, Matthew A. 2017. "Epistemology Personalized." The Philosophical Quarterly 67 (269): 813-834.

. 2018 “God and Interpersonal Knowledge." Res Philosophica 95 (3): 421-447.

Brecht, Mara. 2012. “What's the Use of Exclusivism?.” Theological Studies 73 (1): 3354.

Bohl, Vivian. 2015. "We read minds to shape relationships." Philosophical Psychology 28 (5): 674-694.

Bulkeley, Kelly. 2016. Big Dreams: The Science of Dreaming and the Origins of Religion. Oxford University Press.

Catechism of the Catholic Church. 1997. Liberia Editrice Vaticana. https://www.vatican.va/archive/ENG0015/_INDEX.HTM.

Coakley, Sarah. 2002. "What Does Chalcedon Solve and What Does it Not? Some Reflections on the Status and Meaning of the Chalcedonian 'Definition."' In The Incarnation: An Interdisciplinary Symposium on the Incarnation of the Son of God, edited by Stephen T. Davis, Daniel Kendall, and Gerald O'Collins. Oxford University Press.

Davis, Patricia M. 2005. "Dreams and Visions in the Anglo-Saxon Conversion to Christianity." Dreaming 15 (2):75-88.

D'Costa, Gavin. 2009. Christianity and World Religions: Disputed Questions in the Theology of Religions. Wiley-Blackwell.

Dyer, George J. 1963. Limbo: Unsettled Question. Sheed and Ward. 
Garrett, Greg. 2015. Entertaining Judgement: The Afterlife in Popular Imagination. Oxford University Press.

Hamm, M. Dennis. 2018. "Luke." In The Paulist Biblical Commentary, edited by José Enrique Aguilar Chiu, Richard J. Clifford, Carol J. Dempsey, Eileen M. Schuller, Thomas D. Stegman, and Ronald D. Witherup. Paulist Press.

International Theological Commission. 2007. The Hope of Salvation for Infants who Die without being Baptised. http://www.vatican.va/roman_curia/congregations/cfaith/cti_documents/r c_con_cfaith_doc_20070419_un-baptised-infants_en.html.

Kahan, Tracey L. and Stephen P. LaBerge. 2011. "Dreaming and waking: Similarities and differences revisited." Consciousness and Cognition 20 (3): 494-514.

Keener, Craig S. 1993. The IVP Bible Background Commentary: New Testament. InterVarsity Press.

Kittle, Simon. 2015. "Grace and Free Will: Quiescence and Control." Journal of Analytic Theology. 3: 89-108.

Kozmová, Miloslava. 2017. "Non-lucid dreamers actualize volition as ego executive capacity by engaging in problem solving." International Journal of Dream Research 10 (1): 30-52.

Lewis, C.S. 2002. The Complete C.S. Lewis Signature Classics. HarperOne.

MacCulloch, J.A. 1930. The Harrowing of Hell: A Comparative Study of Early Christian Doctrine. T\&T Clark.

Muthukumarsawamy, Suresh D, and Krish D. Singh. 2008. "Modulation of the human mirror neuron system during cognitive activity." Psychophysiology 45 (6): 896-905.

Need, Stephen W. 1996. Human Language and Knowledge in the Light of Chalcedon. Peter Lang.

Novak, Davis. 2008. “Jewish Eschatology." In The Oxford Handbook of Eschatology, edited by Jerry L. Walls. Oxford University Press.

Occhionero, Michael, and Piercarla Cicogna, 2016. "Phenomenal consciousness in dreams and mind wandering." Philosophical Psychology 29 (7): 958-966.

Plantinga, Richard J., Thomas R. Thompson, and Matthew D. Lundberg. 2010. An Introduction to Christian Theology. Cambridge University Press. 
Poston, Ted and Trent Dougherty. 2007. "Divine hiddenness and the nature of belief." Religious Studies 43 (2): 183-198.

Rutledge, Jonathan C. 2018. "Purgatory, Hypertime, \& Temporal Experience." Journal of Analytic Theology. 6: 151-161.

Senor, Thomas D. 2017. "The Experiential Grounding of Religious Belief." In The Oxford Handbook of the Epistemology of Theology, edited by William J. Abraham and Fredrick D. Aquino. Oxford University Press.

Sliwa, Paulina. 2018. "Know-How and Acts of Faith."' In Knowledge, Belief, and God: New Insights in Religious Epistemology, edited by Matthew A. Benton, John Howthorne, and Dani Rabinowitz. Oxford University Press.

Stump Eleonore. 2018. Atonement. Oxford University Press.

2003. Aquinas. Routledge.

.2010. Wandering in Darkness: Narrative and the Problem of Suffering. Oxford University Press.

Trumbower, Jeffrey A. 2001. Rescue for the Dead: The Posthumous Salvation of NonChristians in Early Christianity. Oxford University Press.

Walls, Jerry L. 2008. "Heaven." In The Oxford Handbook of Eschatology, edited by Jerry L. Walls. Oxford University Press.

. 2002. Heaven: The Logic of Eternal Joy. Oxford University Press.

. 2010. Purgatory: The Logic of Total Transformation. Oxford University Press.

Weinstein, Netta, Rachel Campbell, and Maarten Vansteenkiste, 2018. "Linking psychological need experiences to daily and recurring dreams." Motivation and Emotion 42 (1): 50-63.

Wellington, R.A. 2019. "Divine Revelation as Propositional." Journal of Analytic Theology 7: 156-177.

Yong, Amos. 2007. "Disability, the Human Condition, and the Spirit of the Eschatological Long Run: Toward a Pneumatological Theology of Disability." Journal of Religion, Disability, and Health. 11 (1): 5-25. 